\title{
Carnosol suppresses patient-derived gastric tumor growth by targeting RSK2
}

\author{
Li Wang ${ }^{1}$, Yujuan Zhang ${ }^{1}$, Kangdong Liu' ${ }^{1,2,3,4}$, Hanyong Chen ${ }^{5}$, Ran Yang ${ }^{1}$, Xiaoli \\ Ma $^{1,2}$, Hong-Gyum Kim ${ }^{1}$, Ann M. Bode ${ }^{5}$, Dong Joon Kim ${ }^{1}$ and Zigang Dong ${ }^{1,5}$ \\ ${ }^{1}$ China-US (Henan) Hormel Cancer Institute, Henan, China \\ ${ }^{2}$ The Pathophysiology Department, The School of Basic Medical Sciences, Zhengzhou University, Zhengzhou, Henan, China \\ ${ }^{3}$ The Affiliated Cancer Hospital, Zhengzhou University, Zhengzhou, Henan, China \\ ${ }^{4}$ The Collaborative Innovation Center of Henan Province for Cancer Chemoprevention, Zhengzhou, China \\ ${ }^{5}$ The Hormel Institute, University of Minnesota, Austin, MN, USA \\ Correspondence to: Dong Joon Kim, email: djkim@hci-cn.org \\ Zigang Dong, email: zgdong@hi.umn.edu \\ Keywords: carnosol; RSK2; gastric cancer; patient-derived tumor xenograft \\ Received: September 22, 2017 Accepted: January 09, 2018 Epub: February 06, 2018 Published: September 28, 2018 \\ Copyright: Wang et al. This is an open-access article distributed under the terms of the Creative Commons Attribution License 3.0 \\ (CC BY 3.0), which permits unrestricted use, distribution, and reproduction in any medium, provided the original author and source \\ are credited.
}

\section{ABSTRACT}

Carnosol is a phenolic diterpene that is isolated from rosemary, sage, and oregano. It has been reported to possess anti-oxidant, anti-inflammatory, and anticancer properties. However, the molecular mechanism of carnosol's activity against gastric cancer has not been investigated. Herein, we report that carnosol is an RSK2 inhibitor that attenuates gastric cancer growth. Carnosol reduced anchoragedependent and -independent gastric cancer growth by inhibiting the RSKs-CREB signaling pathway. The results of in vitro screening and cell-based assays indicated that carnosol represses RSK2 activity and its downstream signaling. Carnosol increased the G2/M phase and decreased $S$ phase cell cycle and also induced apoptosis through the activation of caspases 9 and 7 and inhibition of Bcl-xL expression. Notably, oral administration of carnosol suppressed patient-derived gastric tumor growth in an in vivo mouse model. Our findings suggest that carnosol is an RSK2 inhibitor that could be useful for treating gastric cancer.

\section{INTRODUCTION}

Gastric cancer is one of the most common malignant cancers. It is the second most frequently diagnosed cancer and the third leading cause of cancer-related mortality in the world [1]. Although the mortality rate has declined due to improved prevention and treatment, the five-year survival rate of gastric cancer patients is approximately 15 to $35 \%$ [2]. Early detection or diagnosis of gastric cancer is difficult and, thus, most patients are diagnosed at advanced stages. Other difficulties that gastric cancer patients experience include high recurrence rates, metastasis and development of resistance to chemotherapy [3, 4].

The Ras/MAPK (mitogen-activated protein kinase) pathway plays a central role in transducing extracellular signals to intracellular target proteins involved in cell growth, proliferation, cell motility and apoptosis [5]. The RSK (90 kDa ribosomal S6 kinase) is a serine/ threonine kinase that is a downstream effector of the Ras/ ERKs (extracellular signal regulated kinases) signaling pathway [6]. The RSK family contains four isoforms (RSK1 to 4) and is classified structurally as the RSKlike protein kinase/mitogen and stress activated kinase-1 (RLPK/SSK1) and RSK-B (MSK2) [7]. The structure of the RSKs contains two functional kinase domains. The $\mathrm{N}$-terminal kinase domain (NTKD) of RSKs is responsible for downstream substrate phosphorylation, whereas the C-terminal kinase domain (CTKD) of RSKs activates the NTKD through autophosphorylation of the hydrophobic motif [8-10]. RSK1 mRNA is predominantly found in 
the lung, kidney and pancreas, whereas both $R S K 2$ and RSK3 mRNA are more abundant in skeletal muscle, heart and pancreas [7]. RSKs regulate diverse cellular processes including growth, survival and motility, and phosphorylate downstream targets such as CREB [11], c-Fos [12], Bad [13], GSK3 $\beta$ [7], ATF1 [14] and histone H3 [15]. Therefore, RSK is a multifunctional effector of the MAPK signaling pathway as well as an important therapeutic target in various cancers.

Many phytochemicals have been found to possess preventive or therapeutic activities against cancer, presumably without causing severe side effects compared to conventional treatments $[16,17]$. A large amount of cancer research has focused on the identification and development of new chemotherapeutic agents that are derived from plants. A number of different phytochemicals found in the diet have been reported to exert inhibitory effects against various types of cancer cells in vitro and in vivo [18]. For example, rosemary contains various phenolic diterpenes, such as carnosic acid, carnosol and rosmarinic acid, which have been reported to exert antioxidant [19], anti-inflammatory [20], antidiabetic [21] and anticarcinogenic activities [22]. Carnosol is a natural polyphenol compound and is isolated from rosemary, sage and oregano $[23,24]$. The anticancer properties of carnosol include inhibition of cell proliferation, induction of cell apoptosis, and reduction of cell motility mediated through various signaling proteins such as p38 MAP kinase, ERKs, p53, AMPK, activation of caspase 9, and 3, STAT3, NF- $\kappa$ B and COX2 [25-28]. Previous studies suggest that carnosol strongly inhibits TPA/DMBAinduced skin carcinogenesis by suppressing ornithine decarboxylase expression [29]. Additionally, the anticancer activity of carnosol in various animal models has also been reported in a prostate cancer xenograft model [30], in colon carcinogenesis using the $\mathrm{APC}^{\mathrm{min}}$ mouse model [31], as well as in carbon tetrachloride-induced hepatocellular carcinogenesis [32].

Although previous studies suggest that carnosol might be useful in cancer prevention and therapy, the direct molecular targets of carnosol in gastric cancer have not yet been investigated. In this study, we identified direct targets of carnosol and investigated its efficacy against gastric cancer in vitro and in vivo. Herein, we report that carnosol is a potent RSK2 inhibitor that augments the efficacy of gastric cancer treatment.

\section{RESULTS}

\section{Carnosol suppresses gastric cancer cell growth}

Carnosol is an ortho-diphenolic diterpene compound with an abietane carbon skeleton (Figure 1A). To evaluate the effect of carnosol on cytotoxicity, we treated GES1 normal gastric epithelial mucosa cells with this compound. Results showed that carnosol had no cytotoxic effects on GES1 cells (Figure 1B). To determine whether phosphorylated RSK is differentially expressed in normal gastric or gastric cancer cells, we performed Western blot analysis. Results showed that gastric cancer cells highly express phosphorylated RSK compared with normal gastric cells (Supplementary Figure 1). We next determined whether carnosol could affect gastric cancer cell growth. HGC27, SGC7901 or BGC803 gastric cancer cells were treated with various concentrations of carnosol. Results indicated that carnosol significantly inhibited both anchorage-dependent (Figure 1C) and anchorageindependent (Figure 1D) gastric cancer cell growth in a dose-dependent manner.

\section{Carnosol is a potent RSK2 inhibitor}

To identify potential molecular targets of carnosol, we used in vitro kinase assays to screen the effect of carnosol against 14 different kinases. The results indicated that $10 \mu \mathrm{M}$ carnosol strongly suppressed RSK2 activity, but had little effect on any other kinase (Figure 1A). We next determined whether carnosol could affect RSK2 downstream signaling. Following serum starvation for $48 \mathrm{~h}$, JB6 cells were treated with carnosol for $1 \mathrm{~h}$ before treatment with epidermal growth factor (EGF) for $30 \mathrm{~min}$. Results indicated that phosphorylation of CREB, GSK $3 \beta$ and histone H3 was strongly inhibited by carnosol treatment but phosphorylation of RSKs was not affected (Figure 2B). In addition, SGC7901 gastric cancer cells were treated with carnosol for $1 \mathrm{~h}$ and various signaling molecules were analyzed by Western blot. Results indicated that phosphorylation of CREB, GSK $3 \beta$ and histone H3 was substantially inhibited by carnosol treatment, whereas other signaling molecules were not affected (Figure 2C). To confirm whether carnosol has an effect on RSK2 signaling, we performed an in vitro kinase assay using a recombinant active RSK2 protein. These results showed that carnosol exerted strong dose-dependent inhibitory effects against RSK2 autophosphorylation and phosphorylation of its substrate, ATF1 (Figure 2D).

\section{Carnosol directly binds with RSK2}

To further study the potential interaction between carnosol and RSK2, we created a computational docking model (using several protocols in the Schrödinger Suite 2016) of carnosol binding at the ATP pocket of NTD RSK2 and CTD RSK2, respectively. The computational docking model results indicated that carnosol formed several contacts with NTD RSK2 and CTD RSK2 at their respective ATP binding pockets (Figure 3A, 3B). Images were generated with the UCSF Chimera software program [34]. Next, to confirm the computational docking results, we performed in vitro pull-down assays with carnosolconjugated Sepharose 4B beads (or Sepharose 4B beads 
as a negative control) and a recombinant RSK2 protein or SGC7901 and BGC803 gastric cancer cell lysates. Results indicated that carnosol directly binds to RSK2, but not with CREB in cells (Figure 3C, 3D).

\section{Carnosol induces G2/M phase cell cycle arrest}

To evaluate the effect of carnosol on cell cycle in HGC27 or BGC803 gastric cancer cells, we performed flow cytometry (FACS) analysis. Cells were synchronized
A<smiles>CC(C)c1cc2c(c(O)c1O)[C@@]13CCCC(C)(C)[C@H]1CC(C2)OC3=O</smiles>

B

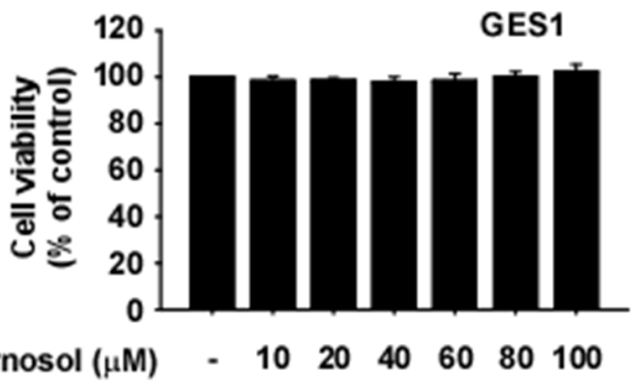

C
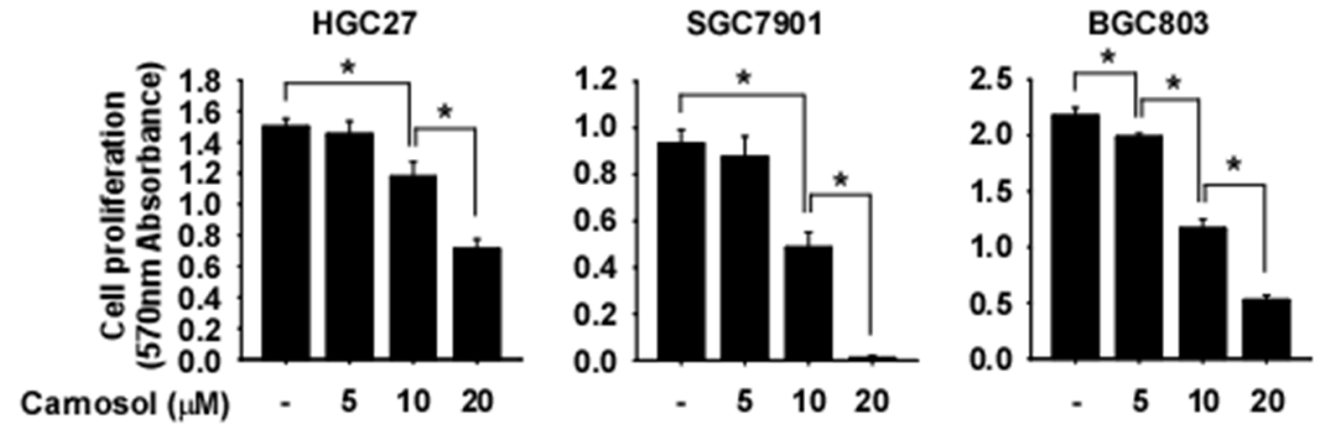

D
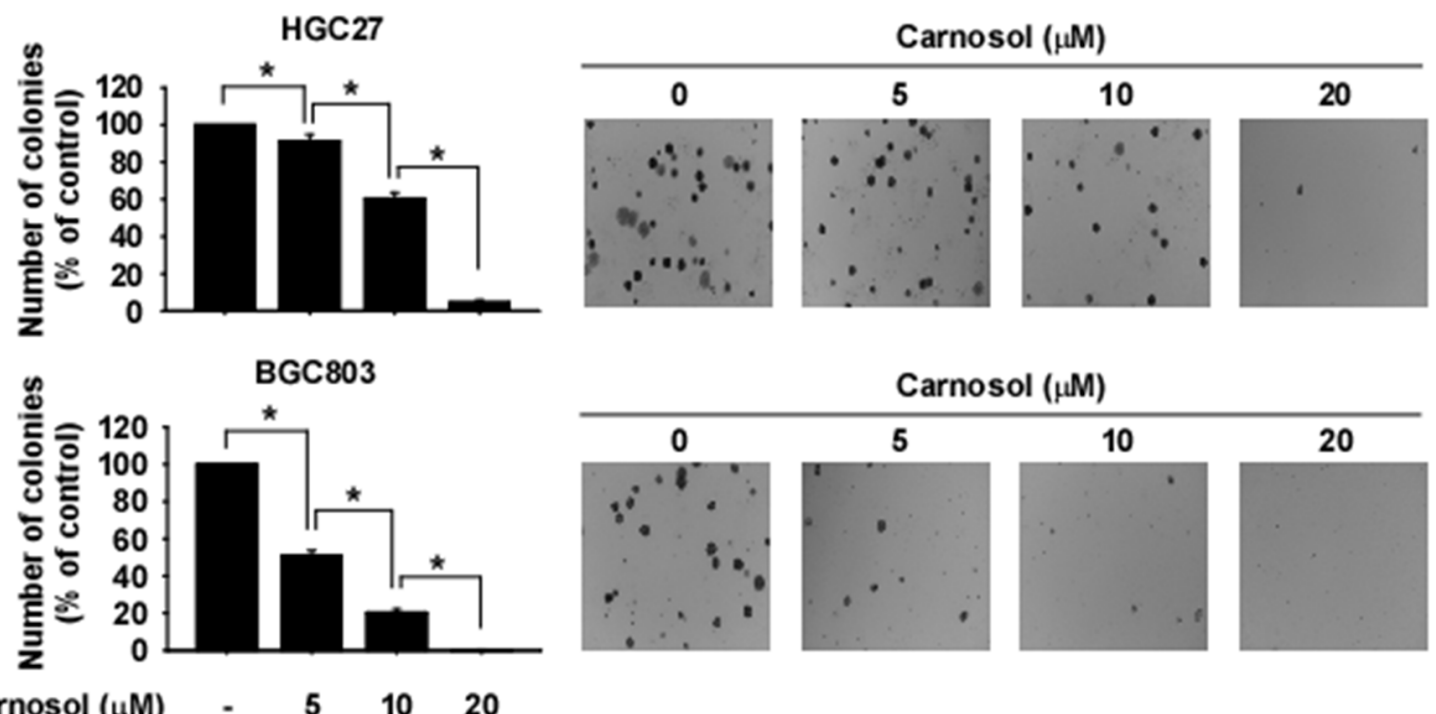

Carnosol $(\mu \mathrm{M}) \quad$ - $\quad 5 \quad 10 \quad 20$

Figure 1: Anti-cancer effects of carnosol. (A) Chemical structure of carnosol. (B) Effect of carnosol on the viability of normal gastric cells. Cells were treated with carnosol for $48 \mathrm{~h}$. (C) Effect of carnosol on gastric cancer cell growth. Cells were treated with carnosol at various concentrations and then incubated for $72 \mathrm{~h}$. For (B and C), cell viability and growth were measured at an absorbance of $570 \mathrm{~nm}$. (D) The effect of carnosol on anchorage-independent growth of gastric cancer cells. Cells were treated with carnosol and incubated for 2 weeks. Colonies were counted using a microscope and the Image-Pro PLUS (v.6) computer software program. All data are shown as means \pm S.D. of triplicate values from 3 independent experiments and the asterisk $\left(^{*}\right)$ indicates a significant $(p<0.05)$ inhibitory effect of carnosol. 


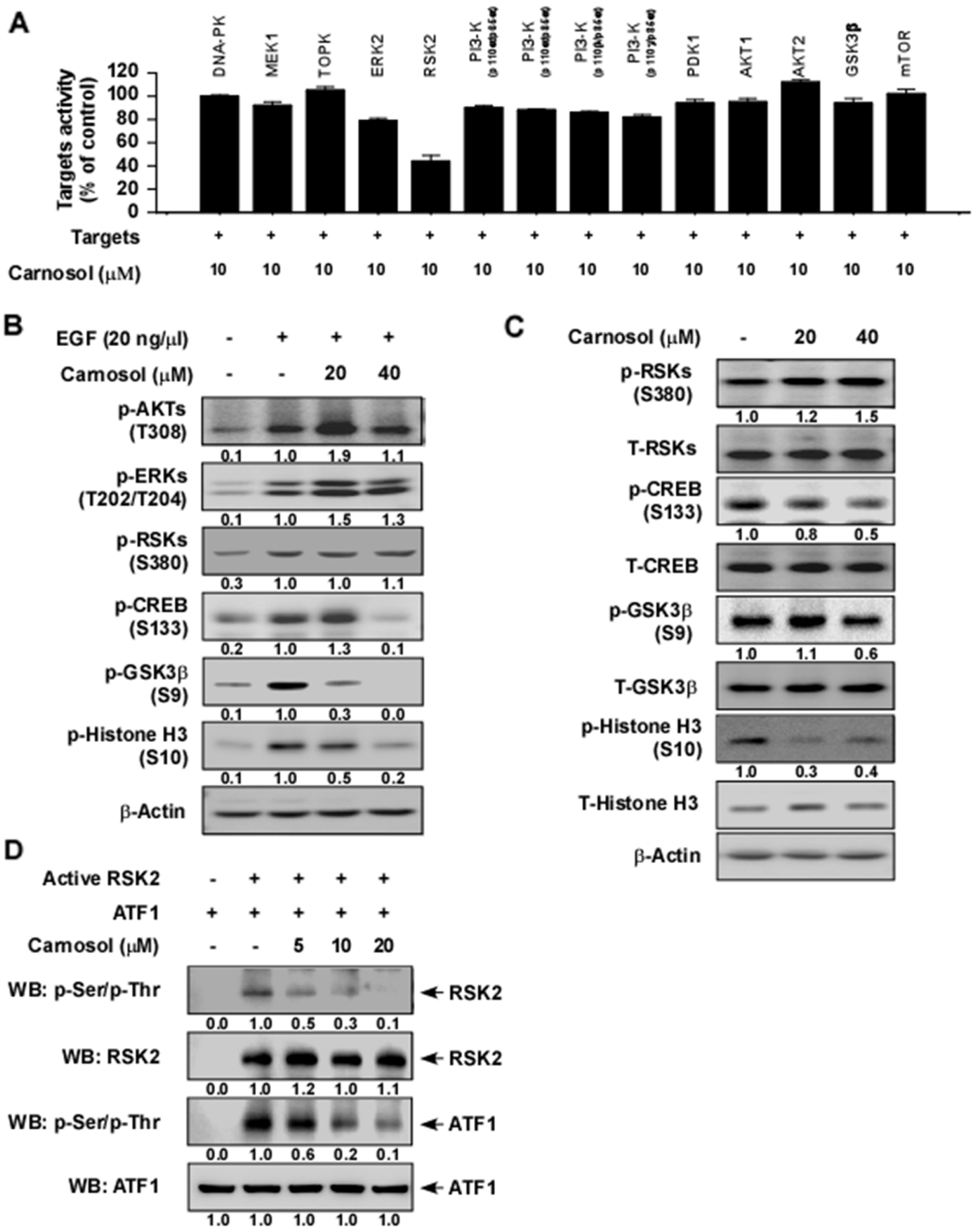

Figure 2: Carnosol is a potent RSK2 inhibitor. (A) Screening ofthe effect of carnosol on various kinases. The effect of carnosol on

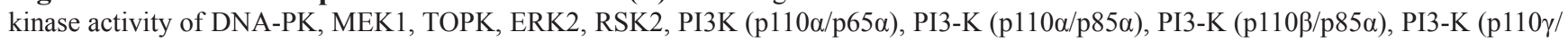
p85 $\alpha$ ), PDK1, AKT1, AKT2, GSK3 $\beta$ or mTOR was determined using active kinases and the specific substrate for each kinase. (B) Effect of carnosol on EGF-induced activation of various signaling proteins in JB6 cells. Serum-starved (0.1\% FBS; 24 h) JB6 cells were treated with various doses of carnosol for $1.5 \mathrm{~h}$ followed by treatment with EGF for $30 \mathrm{~min}$. (C) Effect of carnosol on various signaling proteins in SGC7901 gastric cancer cells. Cells were treated with carnosol at 20 or $40 \mu \mathrm{M}$ for $3 \mathrm{~h}$ and then signaling pathway proteins were examined by Western blotting. (D) Carnosol suppresses RSK2 kinase activity in a dose-dependent manner. The effect of carnosol on RSK2 activity was assessed by an in vitro kinase assay using RSK2 (active, $300 \mathrm{ng}$ ) and ATF1 (substrate, $300 \mathrm{ng}$ ) proteins. The effect of carnosol on RSK2 activity was determined by Western blotting. For (B-D) data, similar results were obtained from 3 independent experiments. 
by serum starvation for $24 \mathrm{~h}$ and cell cycle was released with serum with or without carnosol for $24 \mathrm{~h}$. The results indicated that carnosol induces accumulation of cells in the $\mathrm{G} 2 / \mathrm{M}$ phase and reduces the number of cells in $\mathrm{S}$ phase (Figure 4A, 4B). We also examined the effect of carnosol on cell cycle marker protein expression. Results indicated that expression of cyclin B1 and p53 was increased by carnosol treatment and expression of phosphorylated CDC2 and CDK2 was decreased (Figure 4C).

\section{Carnosol augments gastric cancer cell apoptosis}

To investigate the effect of carnosol on gastric cancer cell apoptosis, we measured the viability of carnosol by

A
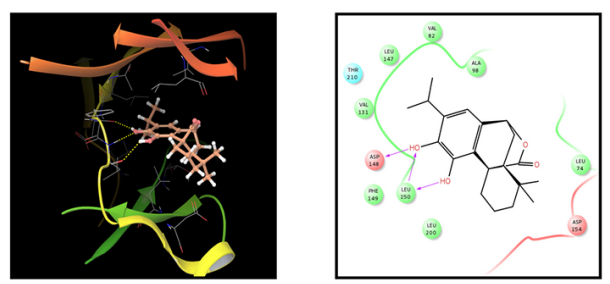

B
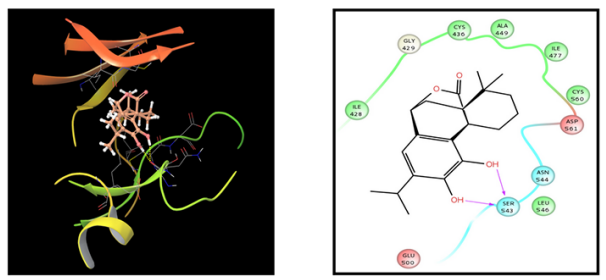

C

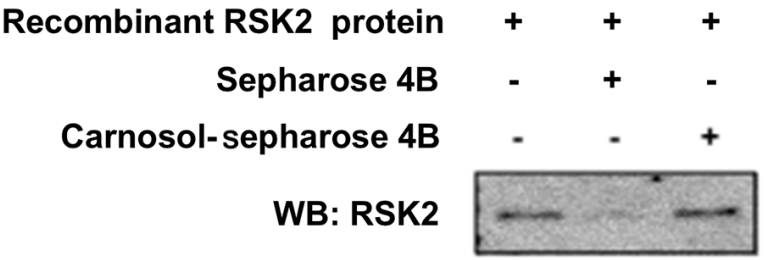

counting SGC7901 or BGC803 gastric cancer cells found in suspended (dead) and attached (live) fractions after treatment for $48 \mathrm{~h}$ with different doses of carnosol. The results indicated that the number of suspended cells was significantly increased in carnosol-treated cells compared with control (Figure 5A, left panel), while that of attached cells was significantly decreased in carnosol-treated cells (Figure 5A, right panel). To determine whether the increased cell death was due to apoptosis, we measured annexin $\mathrm{V}$ expression at $48 \mathrm{~h}$ after carnosol treatment and found a significantly higher level of early apoptosis compared to untreated control cells (Figure 5B-5C). Increased apoptosis was also confirmed by measuring the expression levels of pro-apoptotic or anti-apoptotic marker

D
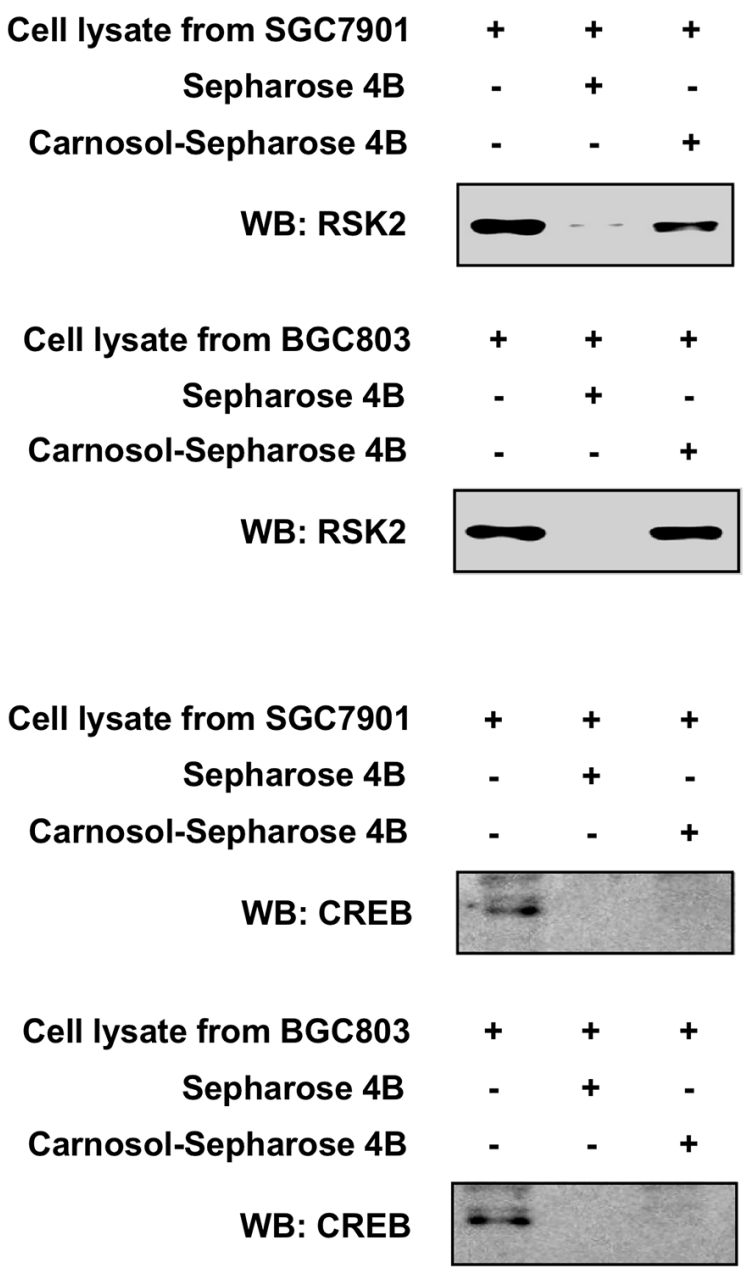

Figure 3: Carnosol directly binds to RSK2. (A) Modeling of carnosol binding with the $\mathrm{N}$ terminal domain (NTD) at the ATP binding pocket (i) of RSK2. Ligand Interaction Diagram (LID) of the binding (right panel). (B) Modeling of carnosol binding with the $\mathrm{C}$ terminal domain (CTD) at the ATP binding pocket (left panel) of RSK2. Ligand Interaction Diagram (LID) of the binding (right panel). The NTD RSK2 and CTD RSK2 structures are shown inas ribbon representation and carnosol is shown as stick representation. Carnosol directly binds to RSK2 using a (C) recombinant protein or (D) gastric cancer cell lysates. The recombinant protein or cell lysate was incubated with carnosol-conjugated Sepharose 4B beads or with Sepharose 4B beads alone. The pulled down proteins were analyzed by Western blotting. Similar results were obtained from 3 independent experiments. 
A

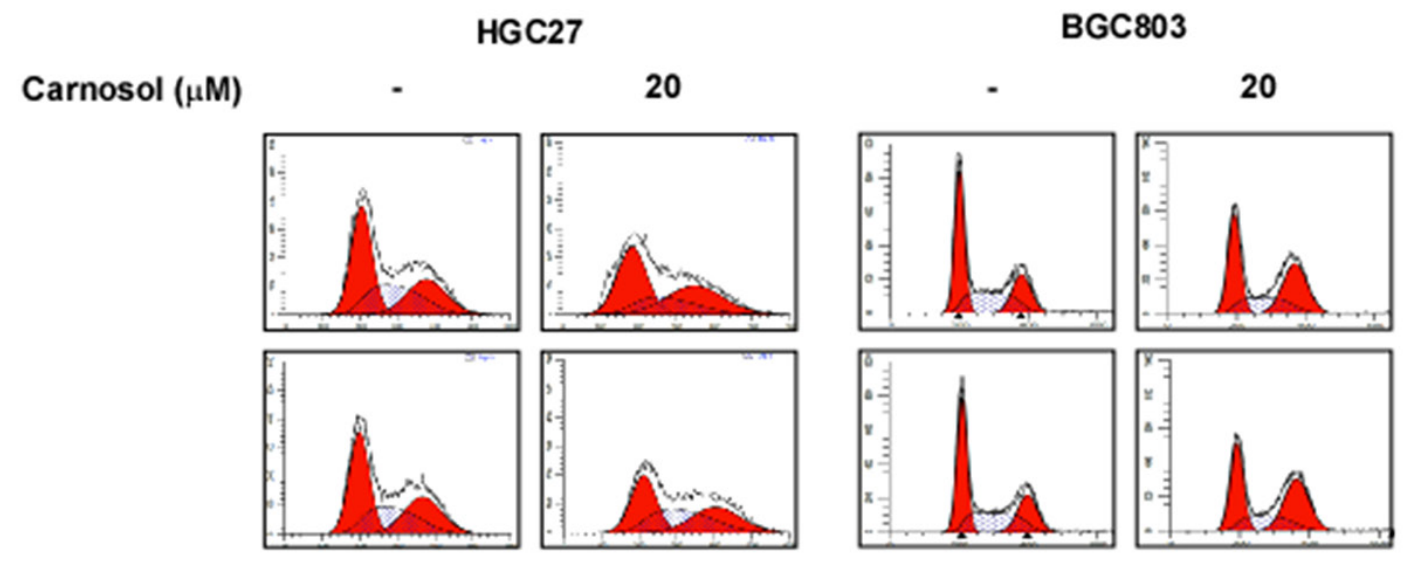

B

HGC27

BGC803
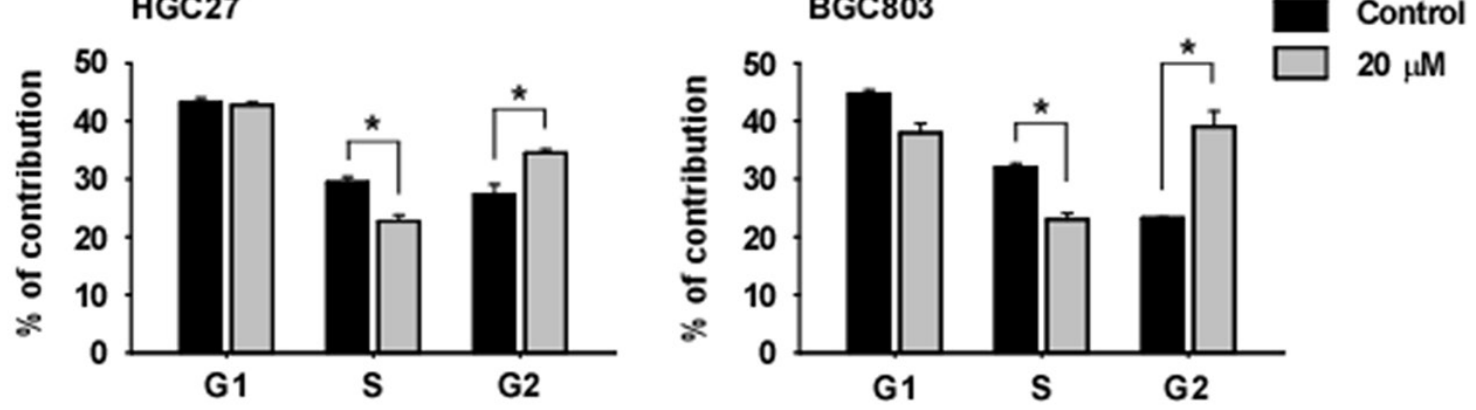

C

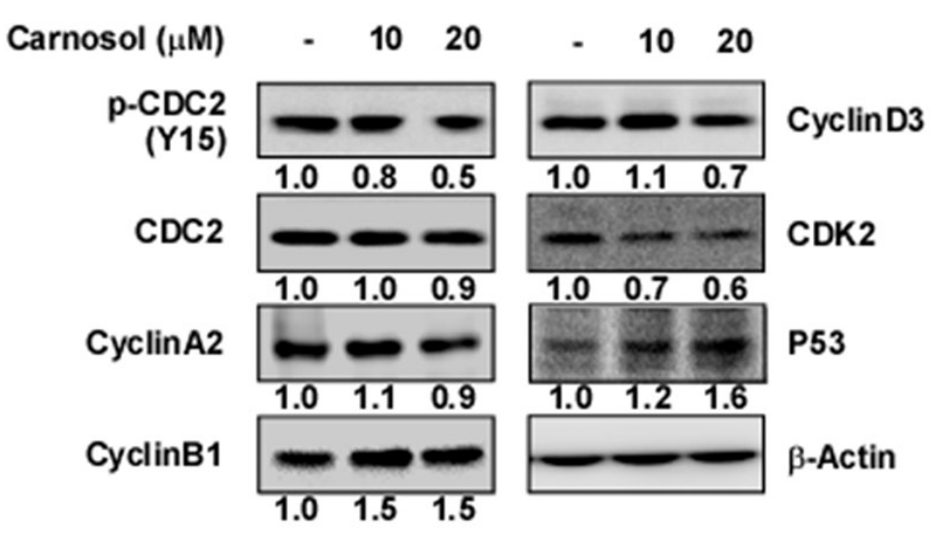

$\square$ Control $\square 10 \mu \mathrm{M} \square 20 \mu \mathrm{M}$
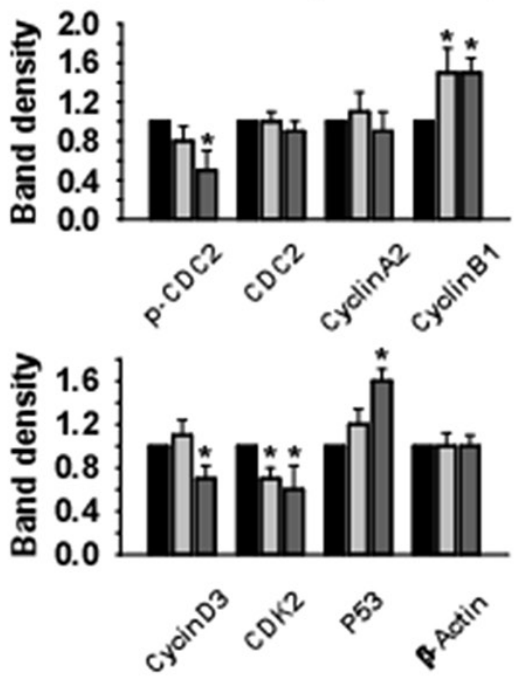

Figure 4: Carnosol induces G2/M phase arrest. (A-B) The effect of carnosol on cell cycle was examined in HGC27 or BGC803 gastric cancer cells. Cells were synchronized by serum starvation for $24 \mathrm{~h}$ and treated with serum and/or carnosol for $24 \mathrm{~h}$ in $10 \%$ serum and medium. Cells were stained with propidium iodide(PI) and cell cycle was analyzed by Fluorescence Activated Cell Sorting (FACS). (C) The effect of carnosol on cell cycle marker proteins was determined. Synchronized cells were treated with serum and/or carnosol for $24 \mathrm{~h}$ in $10 \%$ serum and analyzed by Western blotting. Band density was measured using the Image $\mathrm{J}(\mathrm{NIH})$ software program. For (A-C), similar results were observed from 3 independent experiments. 
proteins and results indicated that cleaved caspase 9 and 7 were strongly induced by carnosol treatment and antiapoptotic BcL-xL was markedly reduced (Figure 5D).

\section{Carnosol inhibits patient-derived gastric tumor growth in vivo}

To examine the anti-tumor activity of carnosol in vivo, patient-derived gastric tumor tissues were injected into the back of the neck of athymic nude mice. Mice were orally administrated carnosol at $100 \mathrm{mg} / \mathrm{kg}$ or vehicle 5 times a week over a period of 31 days. Results indicated that carnosol significantly decreased the volume and weight of gastric tumors relative to the vehicle-treated group (Figure 6A, 6B; $p<0.05$ ). Additionally, mice tolerated treatment with carnosol without significant loss of body weight similar to the vehicle-treated group (Supplementary Figure 2A). We then examined the effects of carnosol on the Ki-67 tumor proliferation marker by using immunohistochemistry. The expression of Ki-67 was significantly decreased by treatment with carnosol (Figure 6C). Furthermore, to evaluate potential toxic effects of carnosol on tissue morphology, the liver and spleen tissues were stained with hematoxylin and eosin (H\&E). Results indicated no obvious morphological changes (Supplementary Figure 2B, 2C). To validate the results of the in vivo PDX model, we investigated the effect of carnosol on RSK2-CREB signaling by Western blot analysis of PDX gastric tumor samples. The phosphorylation of CREB, a direct downstream protein of RSK2, was strongly inhibited in the carnosol-treated group but the expression of total CREB was relatively unchanged (Figure 6D).

\section{DISCUSSION}

Gastric cancer remains one of the most common malignant diseases for which targeted therapies are emerging as treatment options. Promising target therapies by small molecule-induced blockade of the activity of specific oncogenic signaling pathways have been studied. Previous findings indicate that RAS/MAPK signaling is frequently activated by multiple types of genomic amplifications or mutations in gastric cancer [35]. Therefore, targeting of the RAS/MAPK signaling pathways could assist in the application of a molecular targeted therapy against gastric cancer. RSKs are downstream effectors of the MAPK signaling pathway and are heavily involved in tumorigenesis, survival and metastasis of various tumors mediated through their regulation of various substrates, including kinases and transcription factors [7, 8]. Additionally, RSKs are highly activated in various gastric cancer cell types (Supplementary Figure 1). Therefore, RSKs inhibitors might be promising therapeutic agents against gastric cancer. In the present study, we reported that carnosol strongly suppresses RSK2 kinase activity $\left(\mathrm{IC}_{50} \sim 5.5\right.$ $\mu \mathrm{M}$; Figure 2D) and carnosol appears to be most potent against RSK2 compared with other kinases (Figure 2A). Additionally, carnosol significantly suppressed anchoragedependent and -independent gastric cancer cell growth, but had little effect on normal gastric cell growth (Figure 1B-1D).

In previous studies, MAPK signaling was shown to play a role in the G1/S phase transition through cyclin D1 expression $[36,37]$ and also in the G2/M phase transition through the regulation of Myt1 [38] and the CDC2-cyclin B1 complex [39]. During the G2/M phase, the CDC2cyclin $\mathrm{B}$ complex is in an inactive form because of the phosphorylation of CDC2 at Tyr15 by Wee1 and Myt1 $[40,41]$. RSK directly phosphorylates the C-terminal of Myt1 and down-regulates its inhibitory activity against the CDC2-cyclin B complex [38, 41]. Therefore, we suggested that the inhibitory effect against RSK2 activity by carnosol treatment might reduce the phosphorylation of $\mathrm{CDC} 2$ at Tyr15 through regulation of Myt1 activity (Figure 4C). Additionally, RSK leads the G2/M phase transition by activating the phosphorylation of CDC25A and CDC25B [42]. Therefore, we determined whether G2/M phase is arrested by carnosol treatment in gastric cancer cells. Flow cytometric analysis revealed that carnosol induced G2/M phase arrest mediated through changes in cyclin $\mathrm{B} 1, \mathrm{CDK} 2$ and $\mathrm{p} 53$ expression as well as CDC2 activity (Figure 4A-4C).

RSK enhances cell survival through regulation of pro- or anti-apoptotic proteins including $b c l-2, b c L-x L$, bad and caspases activity [43, 44]. Therefore, we investigated whether carnosol could induce cellular apoptosis. Our results suggested that gastric cancer cells underwent increased apoptosis induced by carnosol treatment through the inhibition of the RSK/CREB signaling pathway (Figure 5A-5C). Blocking this signaling pathway resulted in increased cleavage of caspase- 9 and -7 and decreased BcL-xL expression (Figure 5D).

Although advances have occurred in our understanding of human malignancies and molecular mechanisms of cancer biology, only $5 \%$ of anticancer drugs developed have been approved by the Food and Drug Administration (FDA). This is because the pre-clinical testing conducted did not consider tumor heterogeneity and human stromal microenvironmental conditions [45]. Therefore, studying tumor heterogeneity for improving drug efficacy is imperative. To overcome this limitation, researchers developed the patient-derived xenograft (PDX) model, which involves the direct implantation of a patient's primary tumor into compromised immune deficient mice [46]. In the current study, we investigated the antitumor effects of carnosol in gastric PDX models. Results indicated that oral administration of carnosol significantly inhibited gastric tumor growth by inhibiting RSKs/CREB signaling and was not toxic (Figure 6A, 6B and Supplementary Figure 2A-2C). In conclusion, our findings demonstrate that 
A
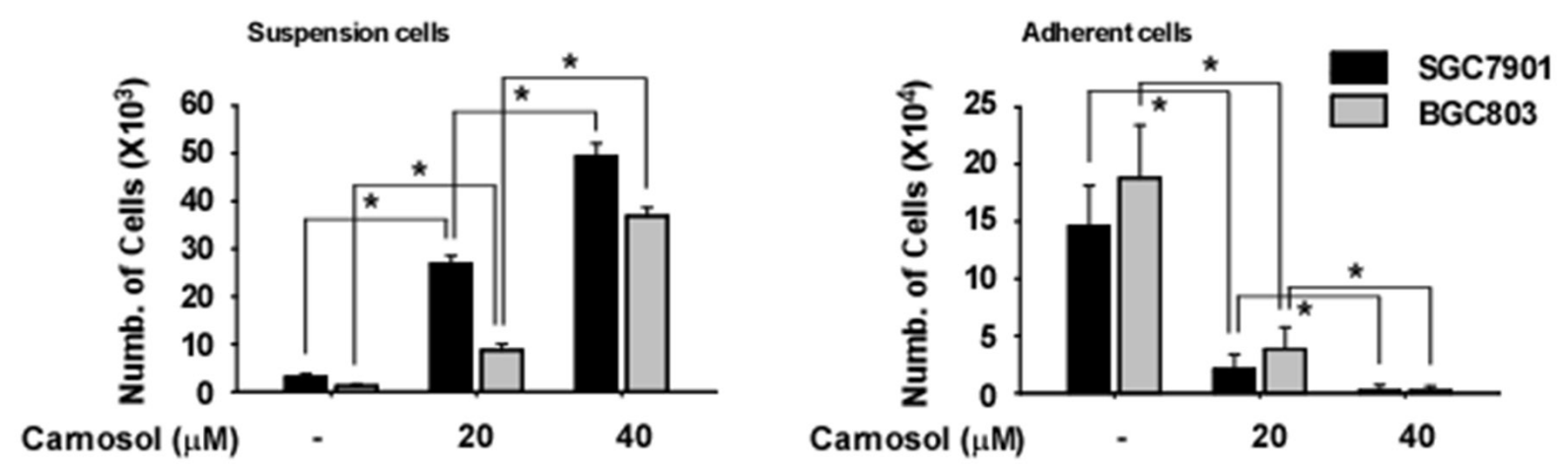

B

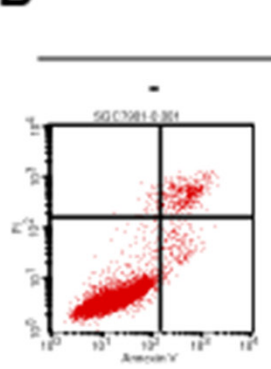

Carnosol $(\mu \mathrm{M})$
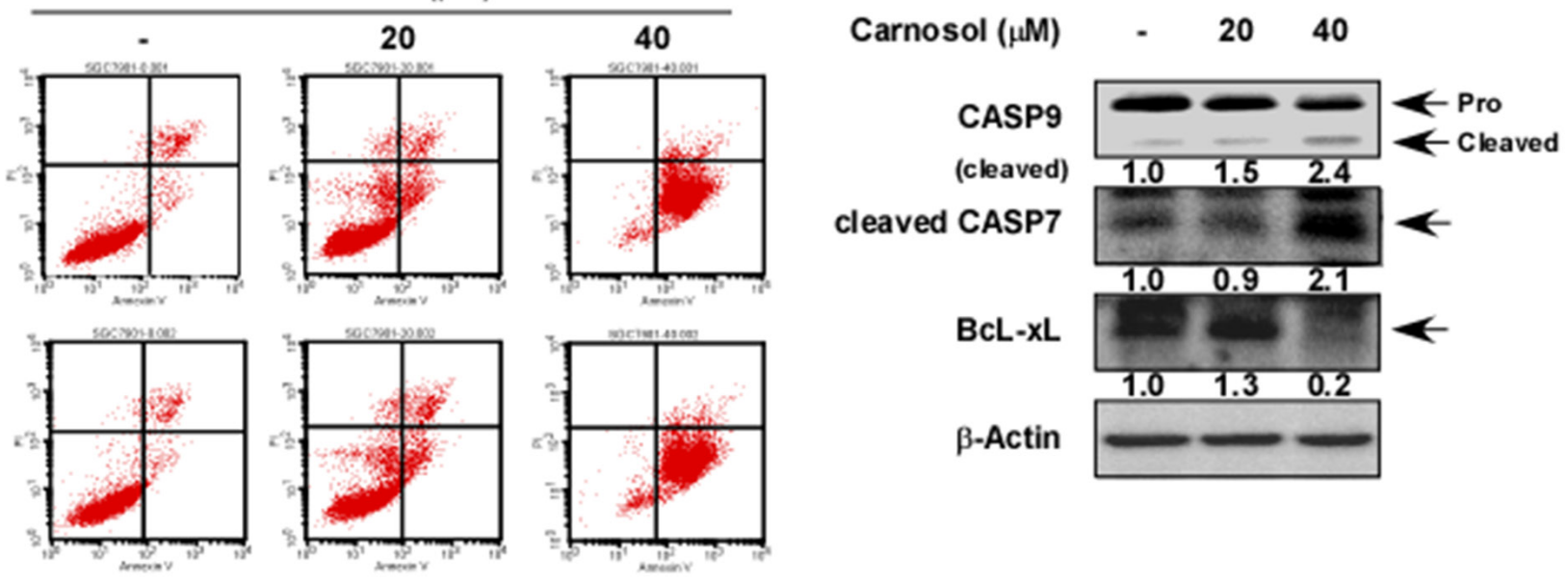

C

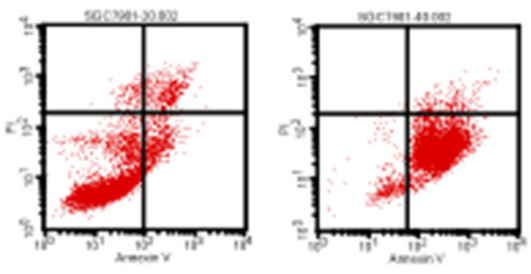

D

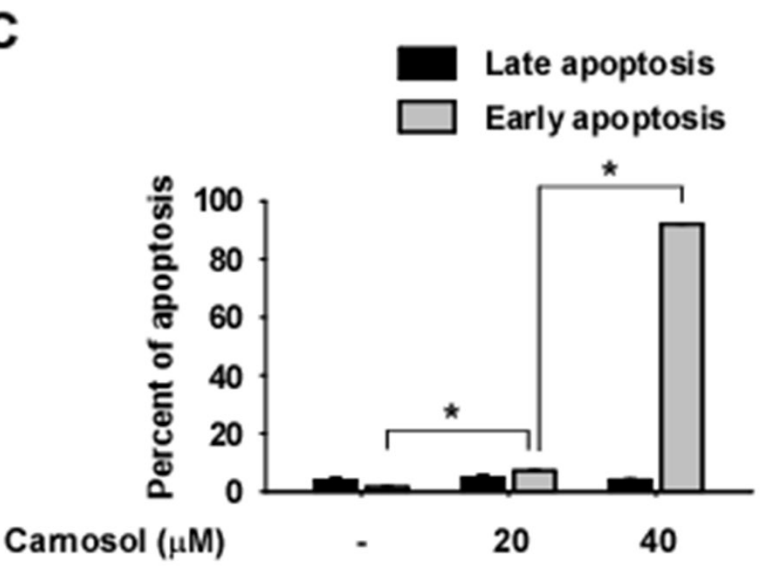

Figure 5: Effect of carnosol on gastric cancer cell apoptosis. (A) Carnosol induces cell death. Cells were seeded in a 6-well plate and treated with carnosol at the indicated doses for $72 \mathrm{~h}$. The number of suspended or attached cells was determined using a hematocytometer. (B-C) Carnosol induces apoptosis. Cells were seeded with carnosol in medium supplemented with $10 \%$ FBS and then incubated for $72 \mathrm{~h}$. Cells were stained with annexin $V$ and propidium iodide(PI) and apoptosis was determined by Fluorescence Activated Cell Sorting (FACS). For $(A-C)$, data are shown as mean values \pm S.D. $(\mathrm{n}=3)$ and the asterisk $\left({ }^{*}\right)$ indicates a significant $(p<0.05)$ difference compared to untreated control cells. (D) Carnosol strongly induces expression of apoptotic marker proteins. Cells were treated with carnosol for $72 \mathrm{~h}$ and the levels of caspase 9 , cleaved caspase 7 and BcL-xL proteins were determined by Western blotting using $\beta$-actin as the loading control. Similar results were observed from 3 independent experiments. Band density was measured using the Image J (NIH) software program. 
A

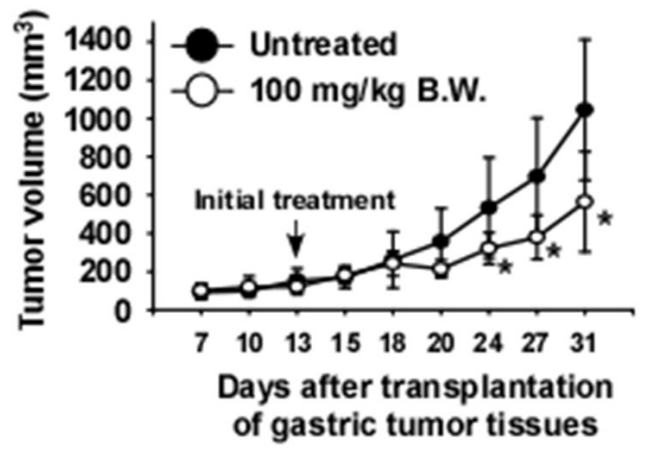

B

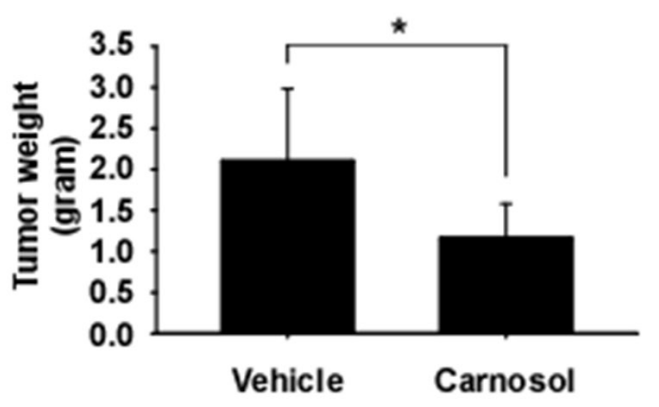

C
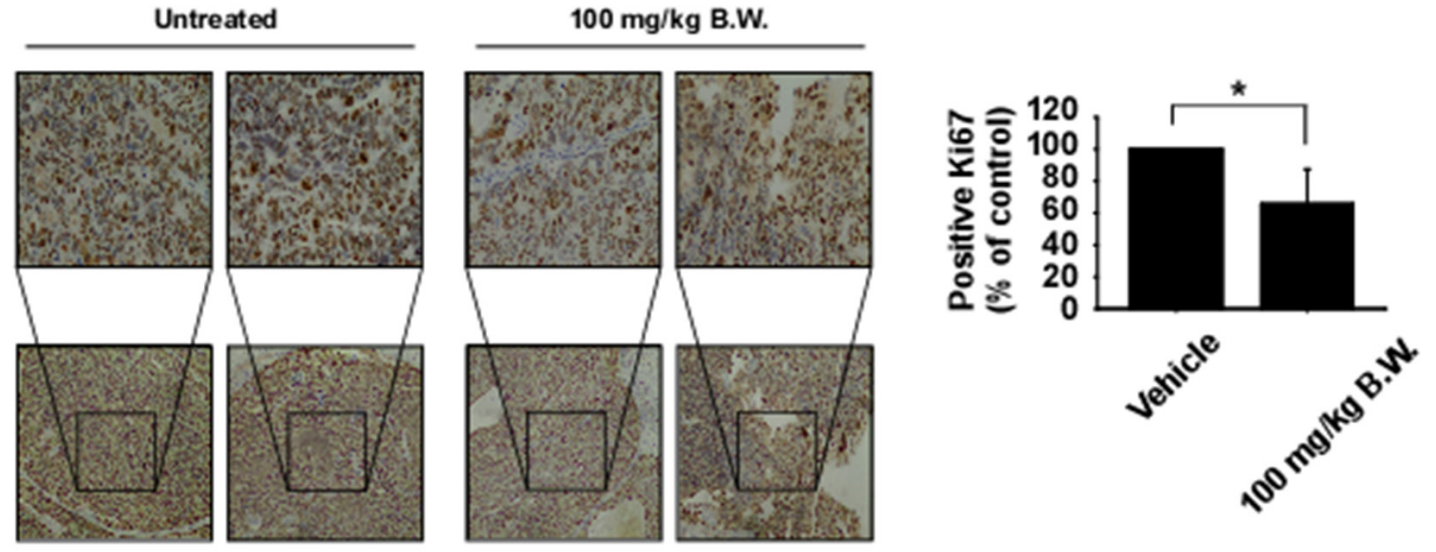

D

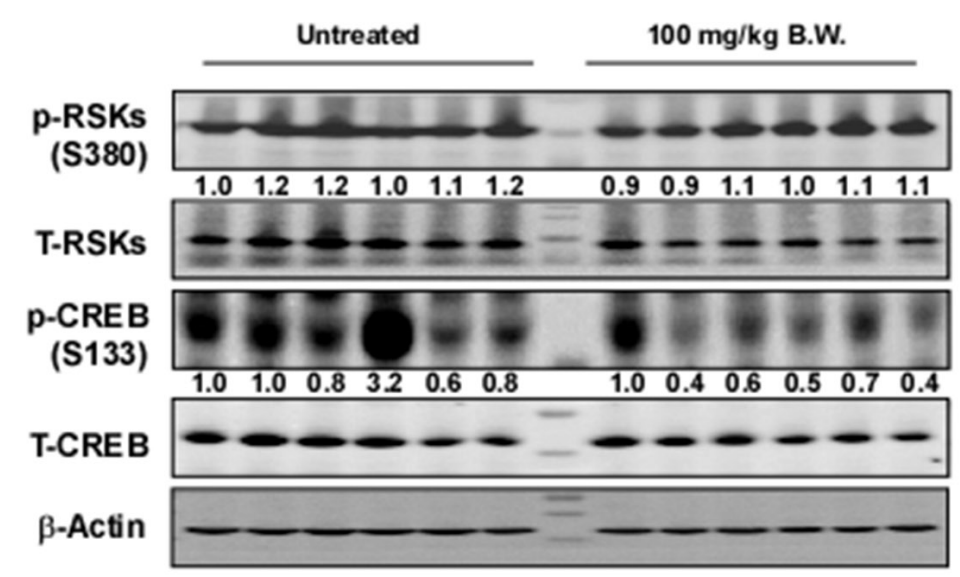

Figure 6: Carnosol attenuates gastric cancer patient-derived xenograft tumor growth in vivo. Mice were divided into 2 groups to assess the effect of carnosol on gastric cancer patient-derived xenograft. Groups are as follows: 1) vehicle group or 2) administration of $100 \mathrm{mg} / \mathrm{kg}$ of carnosol. Mice were orally administered carnosol or vehicle 5 times a week for 18 days. (A-B) Carnosol inhibits gastric tumor growth. For $(\mathrm{A}-\mathrm{B})$, data are shown as means \pm S.E. of values obtained from experiments. The asterisk $\left(^{*}\right)$ indicates a significant difference between tumors from untreated or treated mice as determined by $t$ test $(p<0.05)$. (C) Immunohistochemistry analysis of tumor tissues. Tumor tissues from treated or untreated groups of mice were stained with anti-Ki-67. The number of Ki-67-positive stained cells (right panel) was quantified from immunohistochemistry results $\left(\mathrm{n}=10 ;{ }^{*} ; p<0.05\right)$. (D) Carnosol inhibits RSK-mediated CREB signaling protein expression in gastric tumor tissues. Tumor tissues from each group were immunoblotted with antibodies to detect RSKs, CREB, phosphorylated RSKs, phosphorylated CREB and $\beta$-actin. $\beta$-Actin was used to verify equal protein loading. Band density was measured using the Image J (NIH) software program. 
carnosol is a potent RSK2 inhibitor that could be useful for preventing or treating gastric cancers.

\section{MATERIALS AND METHODS}

\section{Cell lines}

BGC803 and SGC7901 human gastric cancer cells were purchased from KeyGEN BioTECH Corporation (Jiangsu, China). HGC27 human gastric cancer cells were purchased from the Chinese Academy of Sciences Typical Culture Collection (Shanghai, China). GESI human gastric cells were obtained from CHI Scientific, Inc. (Maynard, MA, USA). Enough frozen vials were available for each cell line to ensure that all cell-based experiments were conducted on cells that had been authenticated and in culture for a maximum of 8 weeks. JB6 mouse epidermal cells were cultured in minimal Eagle's medium (MEM) supplemented with 5\% fetal bovine serum (FBS; Biological Industries, Cromwell, CT, USA) and $1 \%$ antibiotic-antimycotic. GES1 or BGC803 human gastric epithelial mucosa cells were cultured in Roswell Park Memorial Institute medium 1640 (RPMI1640) supplemented with 10\% FBS and 1\% antibiotic-antimycotic. HGC27 human gastric cancercells were cultured in Minimum Essential Medium with Earle's Balanced Salts (MEM/EBSS) supplemented with 1\% non-essential amino acid (NEAA), 10\% FBS and $1 \%$ antibiotic-antimycotic. SGC7901 human gastric cancercells were cultured in Dulbecco's Modified Eagle's Medium (DMEM) supplemented with 10\% FBS and 1\% antibiotic-antimycotic.

\section{Reagents and antibodies}

Carnosol (purity: > $>98 \%$ by HPLC) was purchased from Sigma-Aldrich (St. Louis, MO, USA). CNBr-Sepharose 4B beads were from GE Healthcare (Piscataway, NJ, USA). Antibodies to detect total ERKs, phosphorylated ERKs (T202/Y204), total RSK, phosphorylated RSK (S380), total AKT, phosphorylated AKT (S473), phosphorylated CREB (S133), total CREB, phosphorylated CDC2 (Y15), total CDC2, cyclin A2, cyclin B1, cyclin D1, p27(kip1), phosphorylated CDK2 (T160), total CDK2, caspase 9, cleaved caspase 7 and BcL-xL were obtained from Cell Signaling Technology (Beverly, MA, USA). The antibody to detect $\beta$-actin and p21 was from Santa Cruz Biotechnology (Santa Cruz, CA, USA). Active RSK2, and ATF1 (RSK2 substrate) human recombinant protein for kinase assays were purchased from SignalChem (Richmond, BC, Canada).

\section{Anchorage-independent cell growth}

Cells $\left(8 \times 10^{3}\right.$ per well $)$ suspended in complete growth medium (Basal Medium Eagle; BME) supplemented with $10 \%$ FBS were added to $0.3 \%$ agar with or without different concentrations of carnosol in a top layer over a base layer of $0.6 \%$ agar with or without different concentrations of carnosol. The cultures were maintained at $37^{\circ} \mathrm{C}$ in a $5 \% \mathrm{CO}_{2}$ incubator for 2 weeks and then colonies were counted under a microscope using the Image-Pro Plus software (v.6) program (Media Cybernetics, Rockville, MD, USA).

\section{Cell proliferation assay}

To estimate viability, GES1 cells were seeded (3.5 $\times 10^{3}$ cells/well) in 96 -well plates at $37^{\circ} \mathrm{C}$ in a $5 \% \mathrm{CO}_{2}$ incubator and incubated for $24 \mathrm{~h}$. HGC27, SGC7901 or BGC803cells were seeded ( 0.8 to $1 \times 10^{3}$ cells per well) in 96-well plates and incubated for $24 \mathrm{~h}$. Cells were treated with different concentrations of carnosol. After incubation for $48 \mathrm{~h}, 20 \mu \mathrm{l}$ of MTT solution (Solarbio, Beijing, China) were added to each well and the cells were then incubated for $2 \mathrm{~h}$ at $37^{\circ} \mathrm{C}$ in a $5 \% \mathrm{CO}$ incubator. The cell culture medium was removed and $200 \mu \mathrm{l}$ of DMSO were added to each well and crystal formation was dissolved. Absorbance was measured at $570 \mathrm{~nm}$.

\section{Pull-down assay using CNBr-carnosol- conjugated beads}

A recombinant human RSK2 protein (200 ng) or total cell lysates $(500 \mu \mathrm{g})$ were incubated with carnosolsepharose 4B (or sepharose 4B only as a control) beads ( $50 \mu \mathrm{l}, 50 \%$ slurry) in reaction buffer $(50 \mathrm{mM}$ Tris $\mathrm{pH} 7.5$, $5 \mathrm{mM}$ EDTA, $150 \mathrm{mM} \mathrm{NaCl}, 1 \mathrm{mM}$ DTT, 0.01\% NP40, $2 \mu \mathrm{g} / \mathrm{mL}$ bovine serum albumin). After incubation with gentle rocking overnight at $4^{\circ} \mathrm{C}$, the beads were washed 5 times with buffer (50 mM Tris pH 7.5, 5 mM EDTA, 150 $\mathrm{mM} \mathrm{NaCl}, 1 \mathrm{mM}$ DTT, $0.01 \% \mathrm{NP} 40$ ) and binding was visualized by Western blotting.

\section{Computational modeling of RSK2 with carnosol}

To date, no full-length RSK2 crystal structure has been reported. For this study, the crystal structures of CTD (PDB ID:2QR8) and NTD of RSK2 (PDB ID:3G51) [9, 10] were retrieved from the Protein Data Bank (PDB) [33] and used in the computational study. The structures were prepared under the standard procedures of the Protein Preparation Wizard (Schrödinger Suite 2016). Hydrogen atoms were added consistent with a $\mathrm{pH}$ of 7 and all water molecules were removed. The ATP-binding site-based receptor grids of the RSK2 NTD and CTD were generated for docking. Carnosol was prepared using the LigPrep program of Schrödinger Suite 2016 for docking by default parameters. Then the docking of carnosol with NTD RSK2 and CTD RSK2 was accomplished with default parameters under the extra precision (XP) mode using the program Glide. Herein, we could get the bestdocked representative structures. 


\section{Cell cycle analysis}

Cells were plated into 60-mm culture dishes (4$5 \times 10^{4}$ cells/dish) and incubated for $24 \mathrm{~h}$. Cells were synchronized by serum starvation for $24 \mathrm{~h}$ and treated with serum and/or carnosol for $24 \mathrm{~h}$ in $10 \%$ serum and medium. Cells were collected by trypsinization and washed with phosphate buffered saline (PBS) and then fixed in $1000 \mu \mathrm{l}$ of $70 \%$ cold ethanol. After rehydration, cells were digested with RNase $(100 \mu \mathrm{g} / \mathrm{ml})$ and stained with propidium iodide $(20 \mu \mathrm{g} / \mathrm{ml})$. Propidium iodide staining was accomplished following the product instructions (Clontech, Palo Alto, CA, USA). The cells were analyzed by flow cytometry.

\section{Apoptosis assay}

Cells were plated into 6 well culture dishes $(8 \times$ $10^{4}$ cells/well) and incubated for $24 \mathrm{~h}$. Cells were treated with carnosol for $48 \mathrm{~h}$ in $10 \%$ serum-containing medium. Cells were collected by trypsinization and washed with phosphate buffered saline (PBS). Cells were stained with Annexin V (BioLegend, San Diego, CA, USA) and propidium iodide and then apoptosis was analyzed by flow cytomertry.

\section{Patient-derived xenograft (PDX) model}

Female mice with severe combined immunodeficiency (SCID) [6-9 wk old] were maintained under "specific pathogen-free" conditions based on the guidelines established by Zhengzhou University Institutional Animal Care and Use Committee (Zhengzhou, Henan, China). A human tumor specimen of gastric tumor tissue was obtained from the Affiliated Cancer Hospital in Zhengzhou University, cut into pieces and implanted into the back of the neck of each mouse. Mice were divided into 2 groups of 10 animals each as follows: 1) untreated vehicle group and 2) $100 \mathrm{mg}$ carnosol $/ \mathrm{kg}$ of body weight. Carnosol or vehicle (5\% DMSO in $10 \%$ tween 80 ) was orally administered 5 times per week. Tumor volume was calculated from measurements of 2 diameters of the individual tumor base using the following formula: tumor volume $\left(\mathrm{mm}^{3}\right)=($ length $\times$ width $\times$ height $\times 0.52)$. Mice were monitored until tumors reached $1.5 \mathrm{~cm}^{3}$ total volume, at which time mice were euthanized and tumors extracted.

\section{Hematoxylin and eosin staining and immunohistochemistry}

Tumor, liver or spleen tissues from mice were embedded in paraffin blocks and subjected to hematoxylin and eosin (H\&E) staining and immunohistochemistry (IHC). Tissue sections were deparaffinized and hydrated then permeabilized with $0.5 \%$ Triton X-100/1 $\times$ PBS for $10 \mathrm{~min}$. After developing with 3, 3'-diaminobenzidine, the sections were counterstained with H\&E. For IHC, sections were hybridized with the primary antibody (1:500) and a horse-radish peroxidase (HRP)-conjugated goat anti-rabbit or mouse IgG antibody was used as the secondary antibody. All sections were observed by microscope and the ImagePro Plus software (v. 6) program (Media Cybernetics).

\section{Statistical analysis}

All quantitative results are expressed as mean values \pm S.D. or \pm S.E. Significant differences were compared using the Student's $t$ test or one-way analysis of variance (ANOVA). A $p$ value of $<0.05$ was considered to be statistically significant. The statistical package for social science (SPSS) for Windows (IBM, Inc.) was used to calculate the $p$-value to determine statistical significance.

\section{Abbreviations}

RSK2, ribosomal protein S6 kinase 2; CREB, cAMP responsive element binding protein; PDX, patient-derived xenograft; AKT, V-akt murine thymoma viral oncogene homolog; ERKs, extracellular signal-regulated kinases; CDK2, cyclin dependent kinase 2; CDC2, cell division cycle protein 2 .

\section{Author contributions}

L.W. performed the in vitro experiments and assisted with the cell based and in vivo experiments; X.M and H.K. assisted with the cell based assays; Y.Z. and R.Y. performed the in vivo experiments and immunohistochemistry; H.C performed the computer modeling; K.L. and A.M.B. supervised the in vivo experimental design, data analysis and manuscript editing; D.J.K. designed experiments, provided the idea and prepared the manuscript; Z.D. supervised the overall experimental design and data analysis.

\section{ACKNOWLEDGMENTS}

This work was supported by Key program of Henan Province, China Grant NO.161100510300.

\section{CONFLICTS OF INTEREST}

None of the authors have any conflicts of interest.

\section{REFERENCES}

1. Carcas LP. Gastric cancer review. J Carcinog. 2014; 13:14. http://doi.org/10.4103/1477-3163.146506.

2. Patru CL, Surlin V, Georgescu I, Patru E. Current issues in gastric cancer epidemiology. Rev Med Chir Soc Med Nat Iasi. 2013; 117:199-204. 
3. Cervantes A, Roda D, Tarazona N, Rosello S, PerezFidalgo JA. Current questions for the treatment of advanced gastric cancer. Cancer Treat Rev. 2013; 39:60-7. http://doi. org/10.1016/j.ctrv.2012.09.007.

4. Oba K, Paoletti X, Bang YJ, Bleiberg H, Burzykowski T, Fuse N, Michiels S, Morita S, Ohashi Y, Pignon JP, Rougier P, Sakamoto J, Sargent D, et al. Role of chemotherapy for advanced/recurrent gastric cancer: an individual-patientdata meta-analysis. Eur J Cancer. 2013; 49:1565-77. https:// doi.org/10.1016/j.ejca.2012.12.016.

5. Cargnello M, Roux PP. Activation and function of the MAPKs and their substrates, the MAPK-activated protein kinases. Microbiol Mol Biol Rev. 2011; 75:50-83. https:// doi.org/10.1128/MMBR.00031-10.

6. Pearson G, Robinson F, Beers Gibson T, Xu BE, Karandikar M, Berman K, Cobb MH. Mitogen-activated protein (MAP) kinase pathways: Regulation and physiological functions. Endocr Rev. 2001; 22:153-83. https://doi.org/10.1210/ edrv.22.2.0428.

7. Lara R, Seckl MJ, Pardo OE. The p90 RSK family members: Common functions and isoform specificity. Cancer Res. 2013; 73:5301-8. https://doi.org/10.1158/00085472.CAN-12-4448.

8. Anjum R, Blenis J. The RSK family of kinases: Emerging roles in cellular signalling. Nat Rev Mol Cell Biol. 2008; 9:747-58. https://doi.org/10.1038/nrm2509.

9. Malakhova M, Tereshko V, Lee SY, Yao K, Cho YY, Bode A, Dong Z. Structural basis for activation of the autoinhibitory C-terminal kinase domain of p90 RSK2. Nat Struct Mol Biol. 2008; 15:112-3. https://doi.org/10.1038/ nsmb1347.

10. Malakhova M, Kurinov I, Liu K, Zheng D, D’Angelo I, Shim JH, Steinman V, Bode AM, Dong Z. Structural diversity of the active N-terminal kinase domain of $\mathrm{p} 90$ ribosomal S6 kinase 2. PLoS One. 2009; 4:e8044. https:// doi.org/10.1371/journal.pone.0008044.

11. De Cesare D, Jacquot S, Hanauer A, Sassone-Corsi P. Rsk-2 activity is necessary for epidermal growth factor-induced phosphorylation of CREB protein and transcription of c-fos gene. Proc Natl Acad Sci USA. 1998; 95:12202-7.

12. Chen RH, Abate C, Blenis J. Phosphorylation of the c-Fos transrepression domain by mitogen-activated protein kinase and 90-kDa ribosomal S6 kinase. Proc Natl Acad Sci USA. 1993; 90:10952-6.

13. Tan Y, Ruan H, Demeter MR, Comb MJ. p90(RSK) blocks bad-mediated cell death via a protein kinase C-dependent pathway. J Biol Chem. 1999; 274:34859-67.

14. Liu K, Cho YY, Yao K, Nadas J, Kim DJ, Cho EJ, Lee MH, Pugliese A, Zhang J, Bode AM, Dong Z. Eriodictyol inhibits RSK2-ATF1 signaling and suppresses EGFinduced neoplastic cell transformation. J Biol Chem. 2011; 286:2057-66. https://doi.org/10.1074/jbc.M110.147306.

15. Strelkov IS, Davie JR. Ser-10 phosphorylation of histone $\mathrm{H} 3$ and immediate early gene expression in oncogene-transformed mouse fibroblasts. Cancer Res. $2002 ; 62: 75-8$

16. Hosseini A, Ghorbani A. Cancer therapy with phytochemicals: Evidence from clinical studies. Avicenna J Phytomed. 2015; 5:84-97.

17. Russo M, Spagnuolo C, Tedesco I, Russo GL. Phytochemicals in cancer prevention and therapy: truth or dare? Toxins (Basel). 2010; 2:517-51. https://doi. org/10.3390/toxins2040517.

18. Lee KW, Bode AM, Dong Z. Molecular targets of phytochemicals for cancer prevention. Nat Rev Cancer. 2011; 11:211-8. https://doi.org/10.1038/nrc3017.

19. Raskovic A, Milanovic I, Pavlovic N, Cebovic T, Vukmirovic S, Mikov M. Antioxidant activity of rosemary (Rosmarinus officinalis L.) essential oil and its hepatoprotective potential. BMC Complement Altern Med. 2014; 14:225. https://doi.org/10.1186/1472-6882-14-225.

20. Takaki I, Bersani-Amado LE, Vendruscolo A, Sartoretto SM, Diniz SP, Bersani-Amado CA, Cuman RK. Antiinflammatory and antinociceptive effects of rosmarinus officinalis L. essential oil in experimental animal models. J Med Food. 2008; 11:741-6. https://doi.org/10.1089/ jmf.2007.0524.

21. Bakirel T, Bakirel U, Keles OU, Ulgen SG, Yardibi H. In vivo assessment of antidiabetic and antioxidant activities of rosemary (Rosmarinus officinalis) in alloxan-diabetic rabbits. J Ethnopharmacol. 2008; 116:64-73. https://doi. org/10.1016/j.jep.2007.10.039.

22. Ngo SN, Williams DB, Head RJ. Rosemary and cancer prevention: Preclinical perspectives. Crit Rev Food Sci Nutr. 2011; 51:946-54. https://doi.org/10.1080/10408398. 2010.490883.

23. Aruoma OI, Halliwell B, Aeschbach R, Loligers J. Antioxidant and pro-oxidant properties of active rosemary constituents: Carnosol and carnosic acid. Xenobiotica. 1992; 22:257-68.

24. Horiuchi K, Shiota S, Kuroda T, Hatano T, Yoshida T, Tsuchiya T. Potentiation of antimicrobial activity of aminoglycosides by carnosol from Salvia officinalis. Biol Pharm Bull. 2007; 30:287-90.

25. Lo AH, Liang YC, Lin-Shiau SY, Ho CT, Lin JK. Carnosol, an antioxidant in rosemary, suppresses inducible nitric oxide synthase through down-regulating nuclear factor-kappaB in mouse macrophages. Carcinogenesis. 2002; 23:983-91.

26. Subbaramaiah K, Cole PA, Dannenberg AJ. Retinoids and carnosol suppress cyclooxygenase- 2 transcription by CREB-binding protein/p300-dependent and -independent mechanisms. Cancer Res. 2002; 62:2522-30.

27. Johnson JJ, Syed DN, Heren CR, Suh Y, Adhami VM, Mukhtar H. Carnosol, a dietary diterpene, displays growth inhibitory effects in human prostate cancer PC3 cells leading to G2-phase cell cycle arrest and targets the 5'-AMP-activated protein kinase (AMPK) pathway. Pharm Res. 2008; 25:212534. https://doi.org/10.1007/s11095-008-9552-0. 
28. Park KW, Kundu J, Chae IG, Kim DH, Yu MH, Kundu JK, Chun KS. Carnosol induces apoptosis through generation of ROS and inactivation of STAT3 signaling in human colon cancer HCT116 cells. Int J Oncol. 2014; 44:1309-15. https://doi.org/10.3892/ijo.2014.2281.

29. Huang MT, Ho CT, Wang ZY, Ferraro T, Lou YR, Stauber K, Ma W, Georgiadis C, Laskin JD, Conney $\mathrm{AH}$. Inhibition of skin tumorigenesis by rosemary and its constituents carnosol and ursolic acid. Cancer Res. 1994; 54:701-8.

30. Johnson JJ, Syed DN, Suh Y, Heren CR, Saleem M, Siddiqui IA, Mukhtar H. Disruption of androgen and estrogen receptor activity in prostate cancer by a novel dietary diterpene carnosol: Implications for chemoprevention. Cancer Prev Res (Phila). 2010; 3:1112-23. https://doi. org/10.1158/1940-6207.CAPR-10-0168.

31. Moran AE, Carothers AM, Weyant MJ, Redston M, Bertagnolli MM. Carnosol inhibits beta-catenin tyrosine phosphorylation and prevents adenoma formation in the C57BL/6J/Min/+ (Min/+) mouse. Cancer Res. 2005; 65:1097-104.

32. Sotelo-Felix JI, Martinez-Fong D, Muriel De la Torre P. Protective effect of carnosol on $\mathrm{CCl}(4)$-induced acute liver damage in rats. Eur J Gastroenterol Hepatol. 2002; 14:1001-6.

33. Berman HM, Westbrook J, Feng Z, Gilliland G, Bhat TN, Weissig H, Shindyalov IN, Bourne PE. The Protein Data Bank. Nucleic Acids Res. 2000; 28:235-42.

34. Pettersen EF, Goddard TD, Huang CC, Couch GS, Greenblatt DM, Meng EC, Ferrin TE. UCSF Chimera--a visualization system for exploratory research and analysis. J Comput Chem. 2004; 25:1605-12. https://doi.org/10.1002/ jec.20084.

35. Deng N, Goh LK, Wang H, Das K, Tao J, Tan IB, Zhang $\mathrm{S}$, Lee M, Wu J, Lim KH, Lei Z, Goh G, Lim QY, et al. A comprehensive survey of genomic alterations in gastric cancer reveals systematic patterns of molecular exclusivity and co-occurrence among distinct therapeutic targets. Gut. 2012; 61:673-84. https://doi.org/10.1136/ gutjnl-2011-301839.

36. Daksis JI, Lu RY, Facchini LM, Marhin WW, Penn LJ. Myc induces cyclin D1 expression in the absence of de novo protein synthesis and links mitogen-stimulated signal transduction to the cell cycle. Oncogene. 1994; 9:3635-45.

37. Lavoie JN, L'Allemain G, Brunet A, Muller R, Pouyssegur J. Cyclin D1 expression is regulated positively by the $\mathrm{p} 42 /$ p44MAPK and negatively by the p38/HOGMAPK pathway. J Biol Chem. 1996; 271:20608-16.

38. Palmer A, Gavin AC, Nebreda AR. A link between MAP kinase and $\mathrm{p} 34(\mathrm{cdc} 2) /$ cyclin $\mathrm{B}$ during oocyte maturation: p90(rsk) phosphorylates and inactivates the p34(cdc2) inhibitory kinase Myt1. EMBO J. 1998; 17:5037-47. https:// doi.org/10.1093/emboj/17.17.5037.

39. Liu F, Rothblum-Oviatt C, Ryan CE, Piwnica-Worms H. Overproduction of human Myt1 kinase induces a G2 cell cycle delay by interfering with the intracellular trafficking of Cdc2-cyclin B1 complexes. Mol Cell Biol. 1999; 19:5113-23.

40. Parker LL, Piwnica-Worms H. Inactivation of the p34cdc2cyclin B complex by the human WEE1 tyrosine kinase. Science. 1992; 257:1955-7.

41. Booher RN, Holman PS, Fattaey A. Human Myt1 is a cell cycle-regulated kinase that inhibits $\mathrm{Cdc} 2$ but not Cdk2 activity. J Biol Chem. 1997; 272:22300-06.

42. Wu CF, Liu S, Lee YC, Wang R, Sun S, Yin F, Bornmann WG, Yu-Lee LY, Gallick GE, Zhang W, Lin SH, Kuang J. RSK promotes $\mathrm{G} 2 / \mathrm{M}$ transition through activating phosphorylation of Cdc25A and Cdc25B. Oncogene. 2014; 33:2385-94. https://doi.org/10.1038/onc.2013.182.

43. Doehn U, Hauge C, Frank SR, Jensen CJ, Duda K, Nielsen JV, Cohen MS, Johansen JV, Winther BR, Lund LR, Winther O, Taunton J, Hansen SH, et al. RSK is a principal effector of the RAS-ERK pathway for eliciting a coordinate promotile/invasive gene program and phenoty pe in epithelial cells. Mol Cell. 2009; 35:511-22. https://doi. org/10.1016/j.molcel.2009.08.002.

44. Xing J, Ginty DD, Greenberg ME. Coupling of the RASMAPK pathway to gene activation by RSK2, a growth factor-regulated CREB kinase. Science. 1996; 273:959-63.

45. Hutchinson L, Kirk R. High drug attrition rates - where are we going wrong? Nat Rev Clin Oncol. 2011; 8:189-90.

46. Cassidy JW, Caldas C, Bruna A. Maintaining Tumor Heterogeneity in Patient-Derived Tumor Xenografts. Cancer Res. 2015; 75:2963-68. https://doi.org/10.1158/0008-5472. CAN-15-0727. 